\title{
The experience and excellence of the Hospital for Rehabilitation of Craniofacial Anomalies, University of São Paulo (HRAC/USP), in the rehabilitative treatment of cleft lip and palate
}

\author{
Carlos Ferreira SANTOS ${ }^{1}$, Gustavo Pompermaier GARLET ${ }^{2}$ \\ 1- Editor-in-Chief - Journal of Applied Oral Science \\ 2- Co-Editor-in-Chief - Journal of Applied Oral Science
}

Dear Readers,

The Hospital for Rehabilitation of Craniofacial Anomalies, University of São Paulo (HRAC/USP), a world class reference in the treatment of cleft lip and palate and hearing loss, was born in the 1960's decade in the heart of the Bauru School of Dentistry, University of São Paulo (FOB/USP).

During the development of an epidemiologic research project, Professor José Alberto de Souza Freitas ("Tio Gastão"), noticed the critical requirement of specialized care to the patients affected by cleft lip and palate and hearing loss. With the sufferings of the patients presenting facial anomalies as a central motivation, the group started working in a groundbreaking project to build a hospital exclusively dedicated to treat these patients. Along with a group of professors and with the support of FOB/USP, a modest initiative to improve the quality of life of some patients was in fact the cornerstone that resulted in the HRAC/USP.

Upon its creation, in a relatively small town located in the center of São Paulo state, in a critical period (Brazilian government was under the control of military dictatorship) with scarce funds to the development of any project, the HRAC/USP created its own environment in order to evolve and overcome the challenge to bring into the academy a critical social and health problem.

Despite the entire unfavorable scenario, the dream came true. Today, 46 years after its creation, it is amazing to see that more than a world class reference in patients care and in the research in the cleft lip and palate field, the HRAC/USP keeps in its essence the humanistic philosophy that motivated its creation.

Since the beginning, Tio Gastão knew that the difficulties in the care of cleft lip and palate patients were not restricted to medical/scientific procedures and financial issues (related to housing, transportation and nourishment during the treatment), being the emotional marks of curious and repulsive looks a major wound to be healed. Therefore, kindness and respect became essential elements in the integral process of cleft lip and palate rehabilitation.

Therefore, along the last editions, it was a pleasure to the Journal of Applied Oral Science to host a series of articles that summarize some of the most relevant scientific advances in the cleft lip and palate management by the HRAC/USP team, in a context of more than 40 years of experience in the field ${ }^{1-5}$.

\section{REFERENCES}

1- Freitas JAS, Almeida AL, Soares S, Neves LT, Garib DG, Trindade-Suedam IK, et al. Rehabilitative treatment of cleft lip and palate: experience of the Hospital for Rehabilitation of Craniofacial Anomalies/USP (HRAC/USP) - Part 4: oral rehabilitation. J Appl Oral Sci. 2013;21(3):284-92.

2- Freitas JAS, Garib DG, Oliveira TM, Lauris RCM, Almeida ALPF, Neves LT, et al. Rehabilitative treatment of cleft lip and palate: experience of the Hospital for Rehabilitation of Craniofacial Anomalies/USP (HRAC/USP) - Part 2: pediatric dentistry and orthodontics. J Appl Oral Sci. 2012;20(2):268-81.

3- Freitas JAS, Garib DG, Trindade-Suedam IK, Carvalho, RM, Oliveira TM, Lauris RCMC, et al. Rehabilitative treatment of cleft lip and palate: experience of the Hospital for Rehabilitation of Craniofacial Anomalies/USP (HRAC/USP) - Part 3: oral and maxillofacial surgery. J Appl Oral Sci. 2012;20(6):673-9.

4- Freitas JAS, Neves LT, Almeida AL, Garib DG, Trindade-Suedam IK, Yaedú RY, et al. Rehabilitative treatment of cleft lip and palate: experience of the Hospital for Rehabilitation of Craniofacial Anomalies/USP (HRAC/USP) - Part 1: overall aspects. J Appl Oral Sci. 2012;20(1):9-15.

5- Freitas JAS, Trindade-Suedam IK, Garib DG, Neves LT, Almeida $A L$, Yaedú RY, et al. Rehabilitative treatment of cleft lip and palate: experience of the Hospital for Rehabilitation of Craniofacial Anomalies/USP (HRAC/USP) - Part 5: institutional outcomes assessment and the role of the laboratory of physiology. J Appl Oral Sci. 2013;21(4):383-90. 